Jurnal Keperawatan Silampari

Volume 5, Nomor 1, Desember 2021

e-ISSN: 2581-1975

p-ISSN: 2597-7482

DOI: https://doi.org/10.31539/jks.v5i1.2978

\title{
MEKANISME KOPING BERHUBUNGAN DENGAN TINGKAT DEPRESI PADA PASIEN DIABETES MELLITUS
}

\author{
Serli Wulan Safitri ${ }^{1}$, Yani Sofiani², Besral $^{3}$ \\ Universitas Kader Bangsa ${ }^{1}$ \\ Universitas Muhammadiyah Jakarta $^{2}$ \\ Universitas Indonesia ${ }^{3}$ \\ Serlisafitri124@gmail.com ${ }^{1}$
}

\begin{abstract}
ABSTRAK
Penelitian ini bertujuan untuk mengidentifikasi hubungan antara mekanisme koping dengan tingkat depresi pada pasien diabetes mellitus. Metode penelitian ini menggunakan pendekatan cross-sectional. Hasil penelitian diperoleh secara statistik didapatkan hubungan antara mekanisme koping dengan tingkat depresi pada pasien diabetes mellitus dengan $\mathrm{p}$ value $=0.000$, kemudian dilakukan juga analisis uji regresi logistic multiple untuk mengetahui variabel yang paling berpengaruh terhadap tingkat depresi, didapatkan bahwa mekanisme koping merupakan predictor dari depresi $(\mathrm{B}=(2.158), \mathrm{SE}=0.587$, Wald $=13.500$, p-value $=0.000$. Simpulan, mekanisme koping berhubungan dengan tingkat depresi. Diabetisi yang menggunakan mekanisme koping yang baik berpeluang 8 kali mengalami depresi ringan. Sebaiknya diabetisi pada saat mengalami masalah baiknya menggunakan mekanisme koping yang baik.
\end{abstract}

Kata Kunci : Diabetes Mellitus, Mekanisme Koping, Tingkat Depresi

\section{ABSTRACT}

This study aims to identify the relationship between coping mechanisms and the level of depression in patients with diabetes mellitus. This research method uses a cross-sectional approach. The results showed a relationship between the testing mechanism and the level of depression in patients with diabetes mellitus with a p-value $=0.000$. Multiple logistic regression analysis was also performed to determine the most influential variable on the level of depression. It was found that coping mechanisms were predictors of depression $(B=(2,158)),. S E=0.587$, Wald $=13,500, p$ value $=0.000$. In conclusion, coping mechanisms are related to the level of depression. People with diabetes who use good coping mechanisms are stabbed eight times experience mild depression. People with diabetes exercise when experiencing problems well, using good coping mechanisms good.

Keywords: Diabetes Mellitus, Coping Mechanism, Depression Level

\section{PENDAHULUAN}

Diabetes Mellitus (DM) merupakan penyakit yang disebabkan oleh gangguan metabolisme yang ditandai dengan meningkatnya kadar glukosa dalam darah atau hiperglikemia akibat kekurangan atau resistensi insulin (American Diabetes Association, 2018). World Health Organization (WHO) mengungkapkan bahwa pada tahun 2030 
prevalensi DM di dunia dapat meningkat 3 kali lipat dimana akan mencapai angka 21,3 juta.

Secara global, Cina memiliki jumlah kasus diabetes tertinggi dengan lebih dari 109 juta orang dewasa yang terkena dan diikuti oleh negara-negara Muslim seperti Indonesia sebagai tujuh besar dengan 10 juta orang dewasa yang terkena pada tahun 2015 (Setyawati et al., 2020; Cho et al., 2018). Indonesia mengalami peningkatan prevalensi diabetes dari 1,1\% menjadi 1,5\% pada tahun 2013 dan meningkat menjadi 2,0\% pada tahun 2018 (Balitbangkes, 2018; Santosa et al., 2019).

International Diabetes Federation (IDF) juga mengungkapkan bahwa pada tahun 2045 diabetisi bisa mencapai 16,7 juta. Hingga 14 Mei 2020, dari 463 juta orang dewasa di dunia prevalensi DM mencapai 9,3\% dengan rentang usia 20-64 tahun. Indonesia menempati urutan ke-6 dengan jumlah diabetisi yang mencapai 10,3 juta. Di Indonesia sendiri, prevalensi DM berdasarkan diagnosis dokter pada penduduk umur $\geq 15$ tahun meningkat menjadi 2\%. Sedangkan di provinsi Sumatera Selatan prevalensi DM sebesar 1,4\%. Di Kota Palembang secara keseluruhan diabetisi pada bulan Agustus 2020 sebanyak 548 orang (Dinkes Kota Palembang, 2020; ADA, 2019).

Prevalensi yang tinggi pada diabetisi bisa dikendalikan dengan cara melaksanakan lima pilar DM salah satunya mengendalikan depresi (KemenKes, 2019). Selain dapat meningkatkan kadar glukosa darah, kehadiran depresi pada diabetisi juga dapat memberikan dampak negatif bagi penderitanya (Edah et al., 2020). Dalam penelitian lain pun menjelaskan bahwa depresi pada diabetisi dapat meningkatkan risiko komplikasi, kontrol glikemik yang buruk, perawatan diri yang buruk dan kualitas hidup diabetisi juga secara signifikan jauh lebih buruk, maka dari itu diabetisi harus mempunyai suatu mekanisme koping (Edah et al., 2020).

Mekanisme koping dapat dibagi menjadi dua yaitu mekanisme koping adaptif dan mekanisme koping maladaptif, mekanisme koping adaptif adalah suatu kebiasaan baru yang merupakan perbaikan dari situasi yang lama dimana menghasilkan adaptasi yang menetap sedangkan mekanisme koping maladaptif adalah perilaku yang menyimpang dan dapat merugikan diri sendiri, keluarga, orang lain bahkan lingkungan sekitar (YasuiFurukori et al., 2019). Mekanisme koping yang digunakan diabetisi jika adaptif maka akan menghasilkan dampak positif yaitu dapat meningkatkan tingkat kepatuhan dalam terapi diabetes mellitus yang akhirnya akan dapat mengontrol kadar glukosa dalam darah, sedangkan bagi diabetisi jika menggunakan mekanisme koping maladaptif akan menurunkan tingkat kepatuhan minum obat dan mengikuti restriksi diet (Molebatsi et al., 2020; Albasheer et al., 2018).

Berdasarkan hal tersebut, maka perlu diketahui bagaimana mekanisme koping yang digunakan diabetisi dalam menghadapi depresi, sehingga perbedaan dalam penelitian ini yaitu tidak hanya mencari hubungan antara mekanisme koping dan variable perancu dengan tingkat depresi tetapi juga mencari hubungan antara variabel perancu dengan mekanisme koping selain itu juga dicari variabel mana yang paling berpengaruh terhadap tingkat depresi. Berdasarkan penjelasan di atas, hal ini dapat menjadi dasar peneliti merumuskan masalah penelitian tentang bagaimana hubungan mekanisme koping dengan tingkat depresi pada pasien DM.

\section{METODE PENELITIAN}

Penelitian ini menggunakan desain cross- sectional. Populasi yang mengalami DM di Puskesmas Ariodillah dan Puskesmas Merdeka sebanyak 500 responden, dengan jumlah sampel sebanyak 152 responden dengan teknik pengambilan sampel yaitu 
purposive sampling. Penelitian ini berfokus untuk mengetahui hubungan antara mekanisme koping dengan tingkat depresi serta mengetahui lebih lanjut variabel mana yang paling berpengaruh terhadap tingkat depresi pada pasien diabetes mellitus di Puskesmas Kota Palembang tahun 2021. Instrument yang digunakan dalam penelitian ini yaitu kuesioner cope inventory yang terdiri dari 28 pernyataan untuk menilai mekanisme koping dan PHQ-9 yang terdiri dari 9 pertanyaan untuk mengukur tingkat depresi. Instrumen penelitian pun sudah dilakukan uji validitas dan reliabilitas, sehingga kuesioner tersebut dapat digunakan.

Pengambilan data dilakukan ketika diabetisi berkunjung ke Puskesmas Ariodillah dan Puskesmas Merdeka Palembang, karena penelitian ini dilakukan pada masa pandemic COVID-19 sehingga peneliti pun menerapkan protokol kesehatan seperti mencuci tangan, memakai masker dan menjaga jarak. Di dalam penelitian ini, uji chi-square pun dilakukan untuk mengetahui hubungan antara mekanisme koping dengan tingkat depresi serta dilakukan juga uji regresi logistic multiple untuk mengetahui variabel mana yang paling berpengaruh terhadap tingkat depresi.

\section{HASIL PENELITIAN Analisis Univariat}

Tabel. 1

Distribusi Responden Pasien DM

\begin{tabular}{lcccc}
\hline \multicolumn{1}{c}{ Variabel } & Mean & SD & Min - Maks & $95 \%$ CI \\
\hline Umur & 55,47 & 7,41 & $45-68$ & $54,28-56,66$ \\
Lama Menderita & 2,72 & 1,01 & $1-5$ & $2,56-2,89$ \\
\hline
\end{tabular}

Berdasarkan tabel 1 didapatkan bahwa rata-rata umur responden adalah 55 tahun dan standar deviasi 7,41. Umur terendah adalah 45 dan tertinggi adalah 68 tahun. Dari tabel tersebut juga terlihat bahwa rata-rata lama responden menderita penyakit sebesar 2,7 tahun dan standar deviasi 1,01. Lama menderita terendah adalah 1 dan lama menderita tertinggi 5 tahun.

Tabel. 2

Distribusi Responden Pasien DM

\begin{tabular}{llcc}
\hline \multirow{2}{*}{ No } & \multicolumn{1}{c}{ Karakteristik } & Frekuensi & Persentase (\%) \\
\hline 1. & Jenis Kelamin & 31 & \\
& Laki-laki & 121 & 20,4 \\
& Perempuan & & 79,6 \\
\hline 2. & Pendidikan & 74 & 48,7 \\
& SD/SMP & 78 & 51,3 \\
& SMA/Perguruan Tinggi & & \\
\hline 3. & Pekerjaan & 21 & 13,8 \\
& Bekerja & 131 & 86,2 \\
\hline Tidak Bekerja & & \\
\hline 4. & Penyakit Penyerta & 69 & 45,4 \\
& Maag & 80 & 52,6 \\
& Hipertensi & 3 & 2,0 \\
\hline
\end{tabular}


Berdasarkan tabel 2 dari 152 responden, dapat diketahui bahwa sebagian besar responden berjenis kelamin perempuan sebanyak 79,6\%. Jumlah responden dilihat dari tingkat Pendidikan responden tidak jauh berbeda. Sebagian besar responden tidak bekerja sebanyak $86,2 \%$, sebagian besar responden mengalami penyakit penyerta hipertensi sebanyak $52,6 \%$.

Tabel. 3

Distribusi Responden Pasien DM

\begin{tabular}{llcc}
\hline No & \multicolumn{1}{c}{ Mekanisme Koping } & Jumlah & Persentase (\%) \\
\hline 1. & Adaptif & 72 & 47,4 \\
2. & Maladaptif & 80 & 52,6 \\
\hline
\end{tabular}

Berdasarkan tabel 3 didapatkan bahwa sebagian besar responden memiliki mekanisme koping maladaptif sebanyak $(52,6 \%)$.

Tabel. 4

Distribusi Responden Pasien DM

\begin{tabular}{llcc}
\hline No & Depresi & Jumlah & Persentase (\%) \\
\hline 1. & Depresi Ringan & 104 & 68.4 \\
2. & Depresi Berat & 48 & 31.6 \\
\hline
\end{tabular}

Berdasarkan tabel 4 didapatkan bahwa sebagian besar responden mengalami depresi ringan sebanyak $104(68,4 \%)$.

\section{Analisa Bivariat}

Tabel. 5

Hubungan Mekanisme Koping, Jenis Kelamin, Pendidikan dan Penyakit Penyerta dengan Tingkat Depresi

\begin{tabular}{|c|c|c|c|c|c|c|c|}
\hline \multirow{3}{*}{ No } & \multirow{3}{*}{ Variabel } & \multicolumn{4}{|c|}{ Tingkat Depresi } & \multirow{3}{*}{$\begin{array}{c}P \\
\text { Value }\end{array}$} & \multirow{3}{*}{$\begin{array}{c}\text { OR } \\
(95 \% \mathrm{CI})\end{array}$} \\
\hline & & \multicolumn{2}{|c|}{ Depresi Ringan } & \multicolumn{2}{|c|}{ Depresi Berat } & & \\
\hline & & $\mathrm{N}$ & $\%$ & $\mathrm{~N}$ & $\%$ & & \\
\hline \multicolumn{2}{|c|}{ Mekanisme Koping } & & & & & \multirow{3}{*}{0,000} & 5.61 \\
\hline 1 & Adaptif & 62 & 86.1 & 10 & 13.9 & & \\
\hline 2 & Maladaptif & 42 & 52.5 & 38 & 47.5 & & $2,5-12.4$ \\
\hline \multicolumn{2}{|c|}{ Jenis Kelamin } & & & & & \multirow{3}{*}{0,154} & 2,21 \\
\hline 1 & Laki-Laki & 25 & 80.6 & 6 & 19.4 & & \\
\hline & Perempuan & 79 & 65.3 & 42 & 34.7 & & $0,84-5.82$ \\
\hline \multicolumn{2}{|c|}{ Tingkat Pendidikan } & & & & & \multirow{3}{*}{0,693} & 0,82 \\
\hline 1 & SD/SMP & 49 & 66.2 & 25 & 33.8 & & \\
\hline 2 & SMA/PT & 55 & 70.5 & 23 & 29.5 & & $0,41-1,62$ \\
\hline \multicolumn{2}{|c|}{ Pekerjaan } & & & & & \multirow{3}{*}{0,113} & 3.14 \\
\hline 1 & Bekerja & 18 & 85.7 & 3 & 14.3 & & \\
\hline & Tidak Bekerja & 86 & 65.6 & 45 & 34.4 & & $0.87-11.2$ \\
\hline \multicolumn{2}{|c|}{ Penyakit Penyerta } & & & & & \multirow{4}{*}{0,023} & - \\
\hline 1 & Maag & 55 & 79.7 & 14 & 20.3 & & \\
\hline 2 & Hipertensi & 47 & 58.8 & 33 & 41.3 & & - \\
\hline 3 & Asam Urat & 2 & 66.7 & 1 & 33.3 & & \\
\hline
\end{tabular}


Berdasarkan tabel 5 didapatkan bahwa hasil uji chi square diperoleh nilai $\mathrm{p}=0.000$, menunjukan bahwa ada hubungan yang signifikan antara mekanisme koping dengan tingkat depresi. Hasil uji chi square diperoleh nilai $\mathrm{p}=0,154$, menunjukan bahwa tidak ada hubungan yang signifikan antara jenis kelamin dengan tingkat depresi. Hasil uji chi square diperoleh nilai $\mathrm{p}=0.693$, menunjukan bahwa tidak ada hubungan yang signifikan antara tingkat pendidikan dengan tingkat depresi. Hasil uji chi square diperoleh nilai $\mathrm{p}=0.113$, menunjukan bahwa tidak ada hubungan yang signifikan antara pekerjaan dengan tingkat depresi. Hasil uji chi square diperoleh nilai $\mathrm{p}=0,023$, menunjukan bahwa ada hubungan yang signifikan antara penyakit penyerta dengan tingkat depresi.

Tabel. 6

Hubungan umur dan lama menderita dengan Tingkat Depresi

\begin{tabular}{lccc}
\hline \multicolumn{1}{c}{ Variabel } & Mean & Standar Deviasi & $\rho$ value \\
\hline Umur dengan Depresi & & & \\
Depresi ringan & 55.96 & 7.3 & \multirow{2}{*}{0.234} \\
Depresi berat & 54.42 & 7.4 & \\
\hline Lama Menderita Penyakit dengan Depresi & & & \\
Depresi Ringan & 2.65 & 0.9 & 0.211 \\
Depresi Berat & 2.88 & 1.0 & \\
\hline
\end{tabular}

Berdasarkan tabel 6 didapatkan hasil uji t didapatkan nilai $\mathrm{p}=0.234$, berarti secara statistik tidak ada perbedaan yang signifikan rata-rata umur antara responden yang mengalami depresi ringan dengan depresi berat. Hasil uji t didapatkan nilai $\mathrm{p}=0,211$, berarti secara statistik tidak ada perbedaan yang signifikan rata-rata lama menderita penyakit pada responden mengalami depresi ringan dengan depresi berat.

Tabel. 7

Hubungan Jenis Kelamin, Pekerjaan, Pendidikan dan Penyakit Penyerta dengan Mekanisme Koping

\begin{tabular}{|c|c|c|c|c|c|c|c|}
\hline \multirow{3}{*}{ No } & \multirow{3}{*}{ Variabel } & \multicolumn{4}{|c|}{ Mekanisme Koping } & \multirow{3}{*}{$\begin{array}{c}P \\
\text { Value }\end{array}$} & \multirow{3}{*}{$\begin{array}{c}\text { OR } \\
(95 \% \mathrm{CI})\end{array}$} \\
\hline & & \multicolumn{2}{|c|}{ Adaptif } & \multicolumn{2}{|c|}{ Maladaptif } & & \\
\hline & & $\mathrm{N}$ & $\%$ & $\mathrm{n}$ & $\%$ & & \\
\hline \multicolumn{2}{|c|}{ Jenis Kelamin } & & & & & \multirow{3}{*}{0.000} & 2.95 \\
\hline 1 & Laki-Laki & 31 & 100 & 0 & 0.0 & & 23.37 \\
\hline & Perempuan & 41 & 33.9 & 80 & 66.1 & & $2.5-5.1$ \\
\hline \multicolumn{2}{|c|}{ Tingkat Pendidikan } & & & & & \multirow{3}{*}{0.071} & 0.52 \\
\hline 1 & SD/SMP & 29 & 39.2 & 45 & 60.8 & & O 0 \\
\hline & SMA/PT & 43 & 55.1 & 35 & 44.9 & & $0.2-1.0$ \\
\hline \multicolumn{2}{|c|}{ Pekerjaan } & & & & & \multirow{3}{*}{0.000} & 2.56 \\
\hline 1 & Bekerja & 21 & 100 & 0 & 0.0 & & $2.0-3.1$ \\
\hline & Tidak Bekerja & 51 & 38.9 & 80 & 61.1 & & $2.0-3.1$ \\
\hline \multicolumn{2}{|c|}{ Penyakit Penyerta } & & & & & \multirow{4}{*}{0.003} & - \\
\hline 1 & Maag & 43 & 62.3 & 26 & 37.7 & & \\
\hline 2 & Hipertensi & 28 & 35.0 & 52 & 65.0 & & - \\
\hline 3 & Asam Urat & 1 & 33.3 & 2 & 66.7 & & \\
\hline
\end{tabular}

Berdasarkan tabel 7 didapatkan hasil uji chi square diperoleh nilai $\mathrm{p}=0.000$, menunjukan bahwa ada hubungan yang signifikan antara jenis kelamin dengan mekanisme koping pada pasien diabetes mellitus. Hasil uji chi square diperoleh nilai 
$\mathrm{p}=0.071$, menunjukan bahwa tidak ada hubungan yang signifikan antara tingkat pendidikan dengan mekanisme koping pada pasien diabetes mellitus. Hasil uji chi square diperoleh nilai $\mathrm{p}=0.000$, menunjukan bahwa ada hubungan yang signifikan antara pekerjaan dengan mekanisme koping pada pasien diabetes mellitus. Hasil uji chi square diperoleh nilai $\mathrm{p}=0.003$, menunjukan bahwa ada hubungan yang signifikan antara penyakit penyerta dengan mekanisme koping pada pasien diabetes mellitus.

Tabel. 8

Hubungan Umur dan Lama Menderita Penyakit dengan Mekanisme Koping

\begin{tabular}{lccc}
\hline \multicolumn{1}{c}{ Variabel } & Mean & Standar Deviasi & $\rho$ value \\
\hline Umur dengan Mekanisme Koping & & & \\
Adaptif & 54.33 & 7.19 & \multirow{2}{*}{0.72} \\
Maladaptif & 56.50 & 7.51 & \\
\hline Lama Menderita Penyakit dengan Mekanisme Koping & & \\
Adaptif & 2.71 & 1.08 & 0.860 \\
Maladaptif & 2.74 & 0.95 & \\
\hline
\end{tabular}

Berdasarkan tabel 8 didapatkan hasil uji t didapatkan nilai $\mathrm{p}=0.72$, berarti secara statistik tidak ada perbedaan yang signifikan rata-rata umur antara responden yang menggunakan mekanisme koping adaptif dan maladaptif. Hasil uji t didapatkan nilai $\mathrm{p}=0.860$, berarti secara statistik tidak ada perbedaan yang signifikan rata-rata lama menderita penyakit pada responden yang menggunakan mekanisme koping adaptif dan maladaptive.

\section{Analisa Multivariat}

Tabel. 9

Regresi Logistic Permodelan Akhir

\begin{tabular}{lcccc}
\hline Variabel Independen & B & p-value & OR & 95\% CI \\
\hline Mekanisme Koping & 2.15 & 0.000 & 8.65 & $2.73-27.34$ \\
Jenis Kelamin & -1.10 & 0.208 & 0.33 & $0.59-1.85$ \\
Pekerjaan & 0.44 & 0.650 & 1.55 & $0.23-10.43$ \\
penyakit penyerta & 0.63 & 0.105 & 1.88 & $0.87-4.02$ \\
Umur & -0.05 & 0.051 & 0.94 & $0.89-1.00$ \\
\hline
\end{tabular}

Berdasarkan tabel 9 didapatkan bahwa ternyata variabel yang berhubungan bermakna dengan tingkat depresi adalah variabel mekanisme koping sebagai variabel independent. Hasil analisis didapatkan Odds Ratio (OR) yang paling dominan adalah variabel mekanisme koping, dengan nilai OR 8,65 yang artinya dengan mekanisme koping yang baik memiliki resiko 8,6 kali lebih tinggi mengalami depresi ringan dibandingkan dengan mekanisme koping maladaptif setelah dikontrol oleh variable confounding (jenis kelamin, pekerjaan dan penyakit penyerta dan umur).

\section{PEMBAHASAN}

\section{Hubungan Umur dan Lama Menderita Penyakit dengan Tingkat Depresi}

Hasil dalam penelitian ini memperlihatkan bahwa tidak ada perbedaan yang signifikan antara umur dengan tingkat depresi. Hal ini sejalan dengan penelitian yang dilakukan oleh Isnaini (2018) dan laporan Riskesdas (2018) dimana diabetisi terbanyak 
pada umur 55-64 tahun. Dijelaskan bahwa faktor usia dapat menurunkan semua fungsi tubuh, tidak terkecuali diabetisi. Bertambahnya usia menyebabkan insulin berada pada kondisi resistensi yang mengakibatkan gula darah tidak stabil sehingga kejadian DM banyak terjadi (Suprapti, 2019; Isnaini, 2018).

Selain itu, di dalam penelitian ini didapatkan bahwa tidak ada perbedaan yang signifikan rata-rata lama menderita penyakit pada responden mengalami depresi ringan dengan depresi berat. Depresi itu dapat terjadi karena salah satunya diabetisi terlalu memikirkan lamanya dia menderita penyakit DM dan kekhawatiran terhadap komplikasi yang akan dialami, lamanya proses dalam pengobatan, merasa tidak berdaya, dan putus asa terhadap penyakit yang dideritanya (Sinatrya \& Wulandhari, 2019; Khan et al., 2019). Tetapi apabila mereka mengalami DM dan menggunakan mekanisme koping yang baik maka depresi dapat dikendalikan serta lama menderita penyakit pun tidak menjadi permasalahan.

\section{Hubungan Jenis Kelamin, Pendidikan, Pekerjaan, Penyakit Penyerta dan Mekanisme Koping dengan Tingkat Depresi}

Di dalam penelitian ini didapatkan bahwa tidak ada hubungan yang signifikan antara jenis kelamin dengan tingkat depresi. Walaupun banyak dari penelitian lain menjelaskan bahwa diabetisi berjenis kelamin perempuan lebih rentan pada depresi salah satunya karena kaitan hormonal. Hal ini sejalan dengan penelitian yang dilakukan oleh Widiyawati \& Aripin (2018) bahwa jenis kelamin berhubungan dengan mekanisme koping yang digunakan. Hal ini mungkin disebabkan oleh perbedaan penggunaan strategi koping. Beberapa penelitian telah menemukan bahwa perempuan cenderung menggunakan strategi koping yang bertujuan mengubah respon emosi mereka terhadap keadaan yang stressfull, sehingga perempuan lebih bisa mengendalikan hal tersebut.

Di dalam penelitian ini didapatkan bahwa tidak ada hubungan yang signifikan antara pekerjaan dengan tingkat depresi. Hal ini sejalan dengan penelitian yang dilakukan oleh (Manoppo et al., 2017; Jovanovski et al., 2017). Hasil menunjukkan bahwa beban kerja dan tekanan yang mereka terima berpengaruh terhadap mekanisme koping yang digunakan, dimana mereka lebih cenderung menerapkan pengendalian diri sebagai strategi koping ketika mereka mengalami stres dalam pekerjaan.

Di dalam penelitian ini didapatkan bahwa ada hubungan yang signifikan antara penyakit penyerta. Hal ini sejalan dengan penelitian yang dilakukan oleh Abdurrozzaq (2017) dimana dapat disimpulkan bahwa semakin berat penyakit penyerta dari diabetes mellitus tipe 2, maka akan semakin tinggi tingkat gejala depresi.

\section{Hubungan Mekanisme Koping dengan Tingkat Depresi}

Ada hubungan yang bermakna antara mekanisme koping dengan tingkat depresi. Dukungan sosial yang dapat diterima oleh partisipan yaitu dukungan dari keluarga, teman, dan tenaga kesehatan. Pemecahan masalah yang dilakukan oleh partisipan jika menggunakan mekanisme koping adaptif yaitu dengan kontrol rutin, perubahan pola makan, olahraga, mencari informasi dan perubahan aktivitas. Selain itu juga adanya depresi pada pasien diabetes mellitus dapat mengakibatkan kontrol glikemik yang buruk, meningkatkan risiko terjadinya penyakit penyerta, perawatan diri yang buruk dan kualitas hidup penderita diabetes mellitus juga secara signifikan jauh lebih buruk (Li et al., 2020; Edah et al., 2019). 


\section{Hubungan Jenis Kelamin, Pendidikan, Penyakit Penyerta dengan Mekanisme Koping}

Didalam penelitian ini didapatkan bahwa ada hubungan yang signifikan antara jenis kelamin dengan mekanisme koping. Beberapa penelitian telah menemukan bahwa perempuan cenderung menggunakan strategi koping yang bertujuan mengubah respon emosi mereka terhadap keadaan yang stressfull, sedangkan laki - laki lebih banyak menggunakan koping yang berfokus pada masalah dalam mengatasi keadaan yang stressfull (Abdollahi et al., 2020).

Di dalam penelitian ini didapatkan bahwa tidak ada hubungan yang signifikan antara pendidikan dengan mekanisme koping. Penelitian ini tidak sejalan dengan penelitian yang dilakukan oleh Hardiyanti \& Permana (2019); Vasanth et al., (2017) yang mengatakan bahwa seorang yang memiliki pendidikan tinggi lebih menggunakan problem focused coping dalam menyelesaikan masalah karena dapat berpikir logis dan berusaha menyelesaikan masalah dengan positif.

Di dalam penelitian ini didapatkan bahwa ada hubungan yang signifikan antara penyakit penyerta dengan mekanisme koping. Hal ini sejalan dengan penelitian yang dilakukan oleh Romani et al., (2018) bahwa penyakit penyerta berhubungan dengan mekanisme koping yang digunakan, adanya penyakit merupakan salah satu faktor eksternal yang mempengaruhi koping. Banyaknya penyakit yang diderita akan menjadi stressor tersendiri bagi pasien sehingga menambah beban pikiran pasien yang akan mempengaruhi koping yang digunakan.

\section{Hubungan Umur dan Lama Menderita dengan Mekanisme Koping}

Di dalam penelitian ini didapatkan bahwa tidak ada perbedaan rata-rata umur responden yang menggunakan mekanisme koping adaptif dengan mekanisme koping maladaptif. Hal ini sejalan dengan penelitian yang dilakukan oleh Chen et al., (2018). Dalam penelitian tersebut orang dewasa yang lebih tua lebih kecil kemungkinannya dibandingkan orang dewasa yang lebih muda untuk menggunakan koping yang berfokus pada masalah dan melaporkan tingkat afek positif yang lebih rendah. Menurut teori psikososial erikson, individu dari berbagai usia menghadapi peristiwa kehidupan yang berbeda dan melanjutkan melalui serangkaian tahap kehidupan perkembangan psikososial dengan berhasil memecahkan konflik sosioemosional utama pada setiap tahap kehidupan.

Didalam penelitian ini didapatkan bahwa tidak ada perbedaan rata-rata lama menderita penyakit yang menggunakan mekanisme koping adaptif dan mekanisme koping maladaptif. Penyakit DM merupakan the great imitator (Yitshak-Sade et al., 2020; KemenKes, 2019). Individu yang telah terdiagnosis diabetes melitus selama bertahun tahun pasti akan menimbulkan situasi emosional yang berbeda dengan situasi emosionalnya pada tahun pertama (Khan et al., 2019).

\section{SIMPULAN}

Sebagian besar responden berjenis kelamin perempuan, sebagian besar responden memiliki pendidikan SMA/PT, sebagian besar responden tidak bekerja, sebagian besar responden mengalami penyakit penyerta hipertensi, sebagian besar responden rata-rata lama menderita DM 3 tahun, dan rata-rata umur responden berada pada usia 55 tahun

Ada hubungan yang signifikan antara mekanisme koping dengan depresi setelah di kontrol oleh variabel konfounding, responden yang memiliki mekanisme koping yang baik (adaptif) mempunyai OR 8 kali lebih tinggi untuk mengalami minimal depression dibandingkan dengan responden dengan mekanisme koping buruk (maladaptif). 


\section{SARAN}

\section{Bagi Pasien Diabetes Mellitus}

Untuk mecegah timbulnya depresi ada beberapa hal yang harus diperhatikan seperti jangan menyalahkan diri sendiri ketika segala perawatan diabetes gagal dilakukan, mengklaim secara sepihak bahwa harapan hidup anda tinggal sedikit karena penyakit DM tidak bisa disembuhkan karena semakin cepat diabetisi menerima kondisi tersebut dan bertanggung jawab mengelola penyakitnya dengan baik, maka semakin baik kondisi (psikologis).

\section{Bagi Puskesmas Palembang}

Bagi petugas kesehatan dalam memberikan asuhan keperawatan pada pasien diabetes mellitus hendaknya tidak hanya memperhatikan dari sisi fisik saja seperti harus minum obar rutin, diet yang harus dijalankan, patuh terhadap makanan yang dilarang tetapi juga memperhatikan dari sisi biopsikospiritual nya seperti bagaimana perasaan yang mereka rasakan.

\section{Bagi Peneliti Selanjutnya}

Diharapkan untuk dapat memperbesar cakupan sampel penelitian, dapat pula penelitian berupa penelitian kualitatif untuk menggali lebih dalam tingkat depresi pada pasien diabetes mellitus. Selain itu peneliti lain dapat membandingkan di wilayah perkotaan dan pedesaan.

\section{DAFTAR PUSTAKA}

Abdollahi, A., Taheri, A., \& Allen, K. A. (2020). Perceived Stress, Self-Compassion and Job Burnout in Nurses: The Moderating Role of Self-Compassion. Journal of Research in Nursing,26(3), 182-191 https://journals.sagepub.com/doi/10.1177/1744987120970612

Abdurrozzaq, A. (2017). Hubungan Kejadian Komplikasi Diabetes Mellitus Tipe 2 dengan Tingkat Gejala Depresi di RSD dr. Soebandi Jember. Universitas Jember. https://repository.unej.ac.id/handle/123456789/83244

ADA. (2019). American Diabetes Association Standars of Medical Crae in Diabetes2019 (Vol. 53, Issue http://publications.lib.chalmers.se/records/fulltext/245180/245180.pdf\%0Ahttps://h dl.handle.net/20.500.12380/245180\%0Ahttp://dx.doi.org/10.1016/j.jsames.2011.03. 003\%0Ahttps://doi.org/10.1016/j.gr.2017.08.001\%0Ahttp://dx.doi.org/10.1016/j.pr ecamres.2014.12

Albasheer, O. B., Mahfouz, M. S., Solan, Y., Khan, D. A., Muqri, M. A., Almutairi, H. A., Alelyani, A. M., \& Alahmed, H. A. (2018). Depression and Related Risk Factors among Patients with Type 2 Diabetes Mellitus, Jazan Area, KSA: A CrossSectional Study. Diabetes and Metabolic Syndrome: Clinical Research and Reviews, 12(2), 117-121. https://doi.org/10.1016/j.dsx.2017.09.014

American Diabetes Association. (2018). Updates to the Standards of Medical Care in Diabetes-2018. Diabetes Care, 41(9), 2045-2047. https://doi.org/10.2337/dc18-

Balitbangkes, K. (2018). Hasil utama Riskesdas 2018: Kementerian Kesehatan RI

Chen, Y., Peng, Y., Xu, H., \& O'Brien, W. H. (2018). Age Differences in Stress and Coping: Problem-Focused Strategies Mediate the Relationship Between Age and Positive Affect. International Journal of Aging and Human Development, 86(4), 347-363. https://doi.org/10.1177/0091415017720890 
Cho, N., Shaw, J., Karuranga, S., Huang, Y., Rocha-Fernandes, J., Ohlrogge, A., \& Malanda, B. (2018). IDF Diabetes Atlas: Global Estimates of Diabetes Prevalence for 2017 and Projections for 2045. Diabetes Research and Clinical Practice, 138, 271-281. DOI: 10.1016/j.diabres.2018.02.023

Dinkes Kota Palembang (2020). Jumlah 10 Penyakit Terbanyak di Kota Palembang. 2020

Edah, J., Goar, S., Odoh, G., Lawal, B., Dayom, P., Sunday, Z., Sawa, I., Obi, C., Ochigbo, E., \& Puepet, F. (2019). Undiagnosed Depression among Adults with Diabetes Mellitus in Jos. Nigerian Journal of Clinical Practice, 23(10), 1431-436. DOI: 10.4103/njcp.njcp_155_20

Hardiyanti, R., \& Permana, I. (2019). Straregi Coping terhadap Stress Kerja pada Perawat di Rumah Sakit: Literatur Review. Jurnal Keperawatan Muhammadiyah, 73-81. http://journal.um-surabaya.ac.id/index.php/JKM/article/view/2599

Internasional Diabetes Federation. (2017). Eighth Edition 2017. In IDF Diabetes Atlas, 8th edition (eighth edi). file:///Users/ximeneacarballo/Downloads/IDF_DA_8e-ENfinal.pdf

Isnaini, N. (2018). Faktor Risiko Mempengaruhi Kejadian Diabetes Mellitus Tipe Dua Risk Factors Was Affects Of Diabetes Mellitus Type 2. Jurnal Keperawatan dan Kebidanan Aisyiyah, 14(1), 59-68. https://ejournal.unisayogya.ac.id/ejournal/index.php/jkk/article/download/550/233

Jovanovski, E., Li, D., Thanh Ho, H. V., Djedovic, V., De Castro Ruiz Marques, A., Shishtar, E., Mejia, S. B., Sievenpiper, J. L., De Souza, R. J., Duvnjak, L., \& Vuksan, V. (2017). The Effect of Alpha-Linolenic Acid on Glycemic Control in Individuals with Type 2 Diabetes. Medicine (United States), 96(21). https://doi.org/10.1097/MD.0000000000006531

KemenKes. (2019). Hari Diabetes Sedunia Tahun 2018. Pusat Data Dan Informasi Kementrian Kesehatan RI, 1-8. https://pusdatin.kemkes.go.id/article/view/19041500002/hari-diabetes-sedunia2018.html

Khan, Z. D., Lutale, J., \& Moledina, S. M. (2019). Prevalence of Depression and Associated Factors among Diabetic Patients in an Outpatient Diabetes Clinic. Psychiatry Journal, 2019, 1-6. https://doi.org/10.1155/2019/2083196

Li, J., Qiu, X., Yang, X., Zhou, J., Zhu, X., Zhao, E., Qiao, Z., Yang, Y., \& Cao, D. (2020). Relationship between Illness Perception and Depressive Symptoms among Type 2 Diabetes Mellitus Patients in China: A Mediating Role of Coping Style. Journal of Diabetes Research, 2020. https://doi.org/10.1155/2020/3142495

Manoppo, M., Wungouw, H., \& Kallo, V. (2017). Hubungan Status Bekerja dengan Tingkat Depresi pada Lanjut Usia di Jemaat Gmim Kyrios Kawiley Kecamatan Kauditan Minahasa Utara. Jurnal Keperawatan UNSRAT, 5(1), 110412. https://ejournal.unsrat.ac.id/index.php/jkp/article/view/15825

Molebatsi, K., Motlhatlhedi, K., \& Wambua, G. N. (2020). The Validity and Reliability of the Patient Health Questionnaire-9 for Screening Depression in Primary Health Care Patients in Botswana. BMC Psychiatry, 20(1), 4-13. https://doi.org/10.1186/s12888-020-02719-5

Riskesdas. (2018). Hasil Utama Riset Kesehatan Dasar (Riskesdas). Journal of Physics A: Mathematical and Theoretical, 44(8), 1-200. https://doi.org/10.1088/1751$8113 / 44 / 8 / 085201$ 
Romani, N. K., Hendarsih, S., \& Asmarani, F. L. (2018). Kecemasan pada Pasien Gagal Ginjal Kronis di Unit Hemodialisa RSUP Dr. Soeradji Tirtonegoro Klaten Association Between Individual Coping Mechanism and Anxiety in Patients of Chronic Renal Failure (CRF) at Unit of Hemodialysis of Dr. Soeradji Tirtonego. Universitas Respasti Yogyakarta

Santosa, A., Gustiawan, A., Putra, R., \& Chasanah, N. (2019). Body Mass Index to Predict Pre-Diabetes. Ethiopian Journal of Health Development, 33(1), 41-48. https://www.ajol.info/index.php/ejhd/article/view/185425

Setyawati, A. D., Ngo, T., Padila, P., \& Andri, J. (2020). Obesity and Heredity for Diabetes Mellitus among Elderly. JOSING: Journal of Nursing and Health, 1(1), 26-31. https://doi.org/https://doi.org/10.31539/josing.v1i1.1149

Sinatrya, Y., \& Wulandhari, L. A. (2019). Deteksi Diabetes Melitus untuk Wanita Dan Penyusunan Menu Sehat dengan Pendekatan Adaptive Neuro Fuzzy Inference System (Anfis) dan Algoritma Genetika (Ga). Jurnal Teknik Informatika, 12(1), 3958. https://doi.org/10.15408/jti.v12i1.9578

Suprapti, D. (2019). Hubungan Pola Makan, Kondisi Psikologis, dan Aktivitas Fisik dengan Diabetes Mellitus pada Lansia di Puskesmas Kumai. Jurnal Borneo Cendekia, 2(1), 1-23. DOI: 10.54411/jbc.v2i1.85

Vasanth, R., Ganesh, A., \& Shanker, R. (2017). Impact of Stress on Type 2 Diabetes Mellitus Management. Psychiatria Danubina, 29, S416-S421. http://www.psychiatria-

danubina.com/UserDocsImages/pdf/dnb_vol29_noSuppl\%203/dnb_vol29_noSuppl $\% 203$ 416.pdf

Widiyawati, W., \& Aripin, Z. (2017). Hubungan Koping Individu dengan Tingkat Depresi pada Penderita Diabetes Melitus (DM) Tipe 2 di Klinik Prima Medika Gedangan Sidoarjo. Universitas Muhammadiyah Gresik. http://eprints.umg.ac.id/id/eprint/4072

Yasui-Furukori, N., Murakami, H., Otaka, H., Nakayama, H., Murabayashi, M., Mizushiri, S., Matsumura, K., Tanabe, J., Matsuhashi, Y., Yanagimachi, M., Nakamura, K., Daimon, M., \& Sugawara, N. (2019). Coping Behaviors and Depressive Status in Individuals with Type 2 Diabetes Mellitus. Annals of General Psychiatry, 18(1), 1-8. https://doi.org/10.1186/s12991-019-0235-5

Yitshak-Sade, M., Mendelson, N., Novack, V., Codish, S., \& Liberty, I. F. (2020). The Association between an Increase in Glucose Levels and Armed Conflict-Related Stress: A Population-Based Study. Scientific Reports, 10(1), 1-6. https://doi.org/10.1038/s41598-020-58679-z 